\title{
Karakteristik fisika air tanah dan air permukaan serta hubungannya dengan kondisi geologi di lereng selatan Gunung Manglayang, Sumedang, Jawa Barat
}

\author{
(Groundwater's and surface water's physical properties and their relationship to \\ geological conditions of the southern slopes of Mount Manglayang, Sumedang, West \\ Java)
}

\author{
Moch Ridfan Trisnadiansyah*1, Yudhi Listiawan*, M. Nursiyam Barkah*, Emi Sukiyah*, \\ M. Sapari Dwi Hadian* \\ * Universitas Padjadjaran, Jl. Raya Bandung Sumedang KM. 21, Hegarmanah, Jatinangor, Kabupaten \\ Sumedang, Jawa Barat, 45363, Indonesia \\ ${ }^{1}$ Corresponding author, Surel: moch13003@mail.unpad.ac.id
}

Paper received: 04-05-2021; revised: 07-12-2021; accepted: 13-01-2022

\begin{abstract}
The research area is located on the southern slope of Mount Manglayang administratively, including the Jatinangor area, Sumedang, which is the location of various universities. This makes the Jatinangor area develop into a new center of economic growth and education so that the demand for groundwater and surface water for the surrounding population also increases. The purpose of this study was to determine the characteristics of groundwater and surface water and their relationship with local geological conditions. Hydrogeological mapping was carried out by measuring the parameters of the physical properties of water to determine the characteristics of water. Meanwhile, geological conditions in the form of secondary data are processed into slope parameters, lineament density, and rock units. The results showed that the groundwater-surface water group was divided into three groups, namely group one (upstream), group two (middle watershed), and group three (downstream). The results also show a close relationship between geological conditions and groundwater-surface water, especially morphological and lithological factors. This research is useful in developing the treasures of knowledge and applications in lecture activities. The practice carried out can be applied in lectures so that they can connect theoretical and practical needs.
\end{abstract}

Keywords: Manglayang; physical properties of groundwater; physical properties of surface water; geological relations

\begin{abstract}
Abstrak
Lokasi penelitian terletak di lereng Selatan Gunung Manglayang yang secara administratif termasuk wilayah Jatinangor, Kabupaten Sumedang yang menjadi lokasi dari berbagai perguruan tinggi. Hal ini menjadikan wilayah Jatinangor berkembang menjadi pusat pertumbuhan ekonomi dan pendidikan baru sehingga kebutuhan air tanah dan air permukaan untuk penduduk sekitar juga meningkat. Tujuan dari penelitian ini adalah untuk menentukan karakteristik air tanah dan air permukaan serta hubungannya dengan kondisi geologi setempat. Pemetaan hidrogeologi dilakukan dengan mengukur sifat fisik air untuk mengidentifikasi karakteristik air. Sementara itu, kondisi geologi berupa data sekunder yang diolah menjadi parameter kemiringan lereng, densitas kelurusan dan satuan batuan. Hasil penelitian menunjukkan bahwa kelompok air tanah-air permukaan terbagi menjadi tiga, yaitu kelompok satu umumnya berada di hulu DAS, kelompok dua umumnya berada di tengah DAS, dan kelompok tiga berada di hilir DAS. Hasil penelitian juga menunjukkan adanya hubungan yang erat antara kondisi geologi dan air tanah-air permukaan khususnya pada faktor morfologi dan faktor litologi. Penelitian ini bermanfaat mengembangkan khasanah pengetahuan dan
\end{abstract}




\section{Jurnal Pendidikan Geografi:}

\section{Kajian, Teori, dan Praktik dalam Bidang Pendidikan dan Ilmu Geografi}

$$
\text { 27(2), 2022, 88-101 }
$$

aplikasi dalam aktivitas perkuliahan. Praktik yang dilakukan dapat diterapkan dalam perkuliahan sehingga mampu menjembatani kebutuhan teoritis dan praktis.

Kata kunci: Manglayang; sifat fisika air tanah; sifat fisika air permukaan; hubungan geologi

\section{Pendahuluan}

Kawasan gunung api memiliki sumber daya alam yang bermanfaat untuk kepentingan hidup manusia. Salah satu sumber daya alam yang dimiliki pada kawasan tersebut adalah sumber daya air, baik air tanah maupun air permukaan. Data dari Badan Pusat Statistik Kabupaten Sumedang (2019) menunjukkan bahwa curah hujan tahunan di wilayah Jatinangor adalah $1.230 \mathrm{~mm} /$ tahun. Curah hujan yang cukup tinggi berpotensi menjadi akuifer produktif di endapan vulkanik yang kemudian muncul sebagai mata air di kaki gunung (Jumhari, Dwi Hadian, Zakaria, \& Hendarmawan, 2019).

Karakteristik geologi endapan vulkanik memiliki kondisi topografi dan batuan yang cukup kompleks. Struktur geologi yang berkembang akan berpengaruh pada sistem aliran air tanah di kawasan tersebut (Ismawan, 2013). Keluarnya air tanah ke permukaan dapat disebabkan oleh pemotongan muka air tanah, kontak antar batuan, kemunculan sesar atau adanya intrusi batuan. Faktor yang mempengaruhi potensi air adalah formasi geologi (batuan yang bersifat permeable akan berbeda dibandingkan pada batuan intrusi yang bersifat impermeable), bentuk lahan, dan kemiringan lereng (topografi) (Taryana, 2015).

Lereng selatan Gunung Manglayang secara administratif termasuk wilayah Jatinangor yang pada awalnya adalah kawasan perkebunan dan pedesaan. Penetapan kawasan Jatinangor sebagai kota pendidikan tinggi telah direncanakan sejak tahun 1980 an (Muslim \& Endyana, 2015) dan saat ini menjadi lokasi dari Perguruan Tinggi Universitas Padjadjaran (UNPAD), Universitas Winaya Mukti (UNWIM), Institut Koperasi Indonesia (IKOPIN), Institut Pemerintahan Dalam Negeri (IPDN), dan Institut Teknologi Bandung (ITB) (Rahman, 2016). Hal ini menjadikan wilayah Jatinangor pada beberapa dekade terakhir berkembang menjadi spusat pertumbuhan ekonomi baru akibat dari meningkatnya kebutuhan perkembangan kawasan Pendidikan (Wahyudi et al., 2019), sehingga kawasan ini menjadi ramai dan banyak ditinggali oleh penduduk asal maupun pendatang. Peningkatan laju pertumbuhan penduduk tersebut menyebabkan kebutuhan air domestik atau rumah tangga terus meningkat (Oki \& Kanae, 2006).

Peningkatan penduduk ini dikhawatirkan akan berdampak negatif kepada pemanfaatan air tanah yang berlebihan seperti penurunan muka air tanah, penurunan kuantitas, dan kualitas air tanah, serta berkurangnya cadangan air tanah (Rolia \& Surandono, 2015). Penelitian tentang karakteristik air tanah dan air permukaan serta hubungannya dengan kondisi geologi perlu dilakukan. Sehingga penelitian ini dapat menjadi salah satu acuan dasar untuk kebijakan tentang strategi pengelolaan air tanah yang lebih baik di wilayah Jatinangor. Selain itu, penelitian ini bermanfaat mengembangkan khasanah pengetahuan dalam aktivitas pembelajaran. Praktik yang dilakukan dapat diterapkan dalam perkuliahan, sehingga mampu menjembatani kebutuhan teoritis dan praktis khususnya dalam kajian kuantitas air tanah. 


\section{Jurnal Pendidikan Geografi:}

\section{Kajian, Teori, dan Praktik dalam Bidang Pendidikan dan Ilmu Geografi}

$$
\text { 27(2), 2022, 88-101 }
$$

\subsection{Geologi Regional}

Berdasarkan Peta Geologi hasil olahan data Hadian et al., (2017), lereng selatan Gunung Manglayang tersusun dari delapan satuan batuan yang terdiri dari batuan produk vulkanik dan batuan sedimen. Sebaran batuan (geologi) di lereng selatan Gunung Manglayang disajikan pada Tabel 1.

\section{Tabel 1. Sebaran Batuan (Geologi) Daerah Penelitian}

\begin{tabular}{|c|c|c|c|}
\hline No & $\begin{array}{l}\text { Kode } \\
\text { Satuan }\end{array}$ & Satuan Batuan & Material Penyusun \\
\hline 1 & Yls & Young Lake Sediment & $\begin{array}{l}\text { Terdiri dari Batupasir, Gravel dan } \\
\text { Konglomerat }\end{array}$ \\
\hline 2 & Yvp & Young Volcanic Product & Terdiri dari Lava Andesit \\
\hline 3 & Ia & Intrusi Andesit & Merupakan Intrusi Andesit \\
\hline 4 & Yvpp2 & $\begin{array}{l}\text { Young Volcanic } \\
\text { Pyroclastic Product } 2\end{array}$ & Terdiri dari Breksi Aliran Piroklastik \\
\hline 5 & Yvpp1 & $\begin{array}{l}\text { Young Volcanic } \\
\text { Pyroclastic Product } 1\end{array}$ & Terdiri dari Breksi Vulkanik, Tuf \\
\hline 6 & Ovvp3 & $\begin{array}{l}\text { Old Volcanic Pyroclastic } \\
\text { Product } 3\end{array}$ & $\begin{array}{l}\text { Terdiri dari Breksi Vulkanik Monomik Grain } \\
\text { Supported }\end{array}$ \\
\hline 7 & Ovvp2 & $\begin{array}{l}\text { Old Volcanic Pyroclastic } \\
\text { Product } 2\end{array}$ & $\begin{array}{l}\text { Terdiri dari Lava Andesit, Breksi Vulkanik } \\
\text { Matrix Supported dan Tuf. }\end{array}$ \\
\hline 8 & Ovpp1 & $\begin{array}{l}\text { Old Volcanic Pyroclastic } \\
\text { Product } 1\end{array}$ & $\begin{array}{l}\text { Terdiri dari Lava, Breksi Vulkanik dan } \\
\text { Aglomerat }\end{array}$ \\
\hline
\end{tabular}

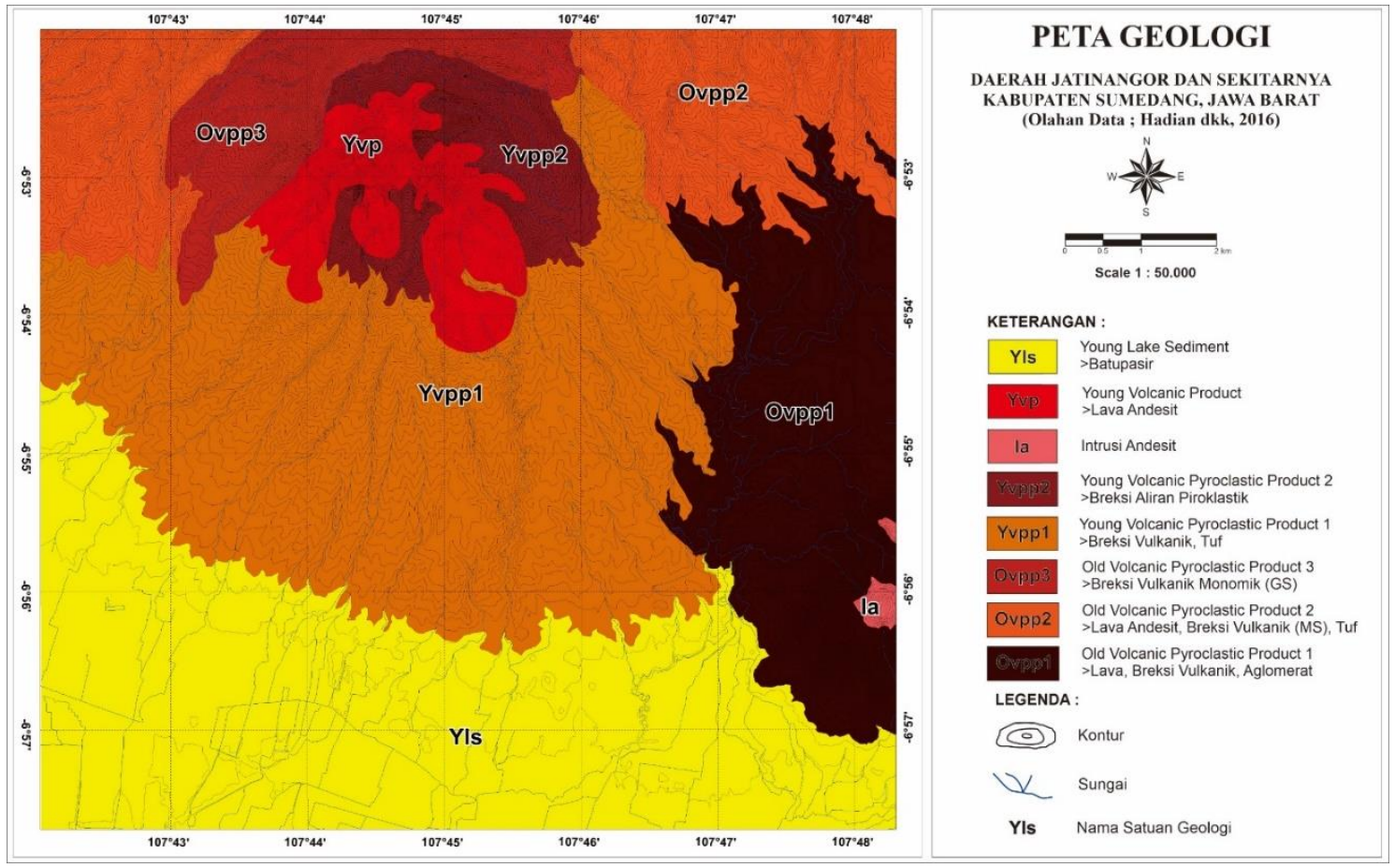

Gambar 1. Peta Geologi Daerah Penelitian Sumber: Hadian et al., (2017) 


\subsection{Hidrogeologi Regional}

Berdasarkan Peta Hidrogeologi Indonesia skala 1:250.000 Lembar V Bandung (Soetrisno, 1983), daerah penelitian terdiri dari tiga jenis akuifer yang berada pada sistem akuifer vulkanik. Jenis-jenis akuifer disajikan pada Tabel 2.

Tabel 2. Keterdapatan Air Tanah dan Produktivitas Akuifer

\begin{tabular}{|c|c|c|c|}
\hline No & Media Akuifer & Produktivitas Akuifer & $\begin{array}{l}\text { Warna (pada } \\
\text { peta) }\end{array}$ \\
\hline 1 & $\begin{array}{l}\text { Akuifer dengan aliran melalui } \\
\text { ruang antar butir }\end{array}$ & $\begin{array}{l}\text { Akuifer penyebaran luas dan } \\
\text { produktif }\end{array}$ & Biru \\
\hline 2 & $\begin{array}{l}\text { Akuifer dengan aliran melalui } \\
\text { ruang antar butir dan celahan }\end{array}$ & $\begin{array}{l}\text { Akuifer penyebaran luas dan } \\
\text { produktivitas sedang } \\
\text { Akuifer produktif setempat }\end{array}$ & $\begin{array}{l}\text { Biru Muda } \\
\text { Hijau Muda }\end{array}$ \\
\hline 3 & Akuifer bercelah atau sarang & $\begin{array}{l}\text { Akuifer daerah air tanah tak } \\
\text { berarti atau langka }\end{array}$ & Oranye \\
\hline
\end{tabular}

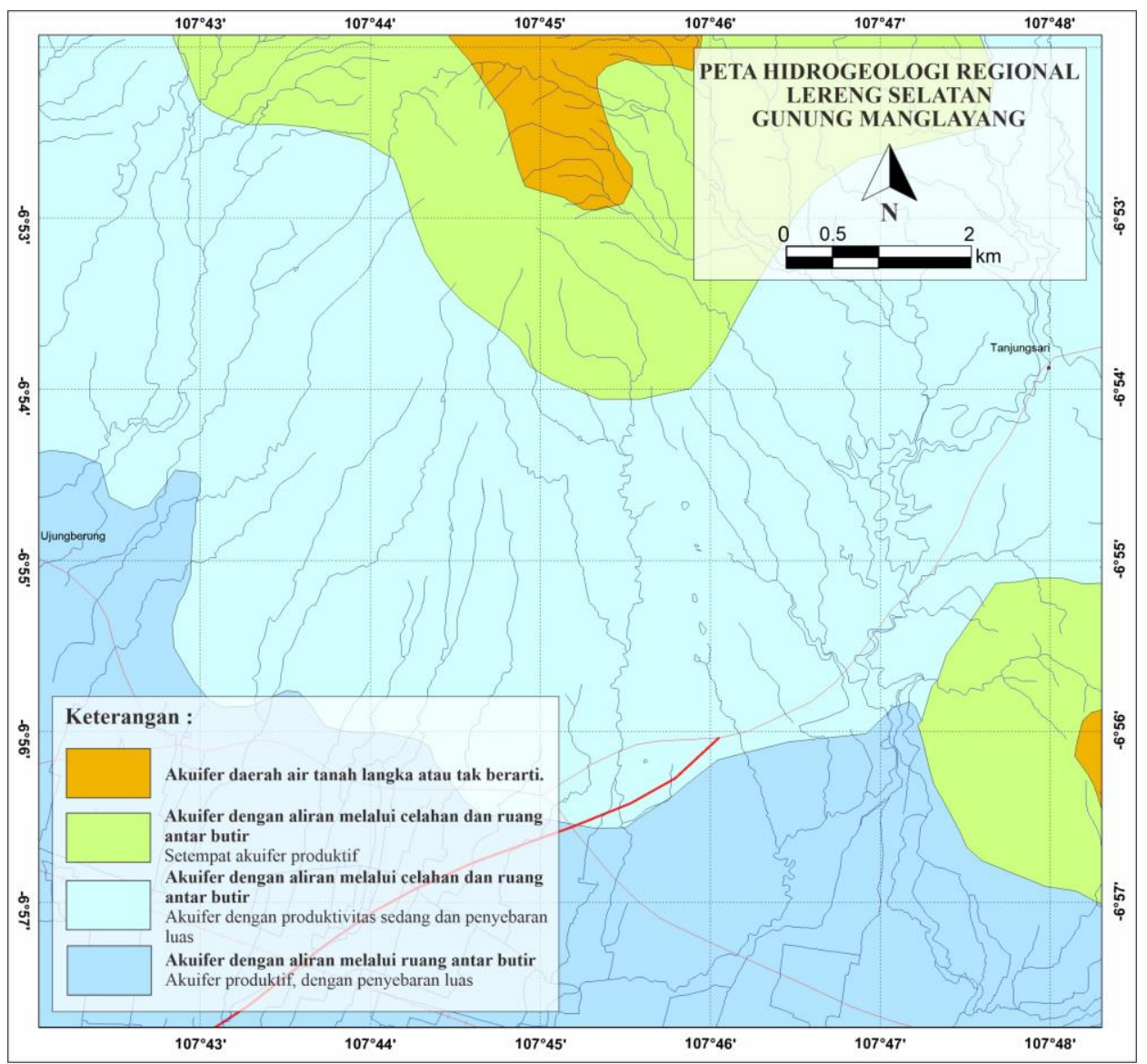

Gambar 2. Peta Hidrogeologi Regional Daerah Penelitian Sumber: (Soetrisno, 1983) 


\section{Metode}

Penelitian dimulai dengan studi pustaka dari berbagai data sekunder terutama data geologi dan hidrogeologi daerah penelitian. Selanjutnya dilakukan pengamatan lapangan untuk mendapatkan data primer untuk melengkapi data sekunder yang telah ada. Secara lebih detail, metode penelitian dari penelitian ini dirancang dalam beberapa aspek uraian, diantaranya:

\subsection{Geomorfologi dan Penginderaan Jauh}

\subsubsection{Kemiringan Lereng}

Analisa kemiringan lereng berkaitan dengan kesempatan air hujan untuk meresap ke dalam tanah (Sugianti, Mulyadi, \& Maria, 2016). Analisa dilakukan dengan menggunakan data Digital Elevation Model (DEMNAS) (Badan Informasi Geospasial, 2018). Klasifikasi Pembagian kelas kemiringan lereng di wilayah penelitian didasarkan pada penelitian Zuidam (1986). Klasifikasinya terbagi kedalam tujuh kelas yang disajikan pada Tabel 3.

Tabel 3. Klasifikasi Kelas Lereng

\begin{tabular}{llll}
\hline \multirow{2}{*}{ Klasifikasi } & \multicolumn{2}{l}{ Kemiringan Lereng } & Warna \\
\cline { 2 - 4 } & Derajat $\left({ }^{\circ}\right)$ & Persen $(\%)$ & \\
\hline Sangat Terjal & $>55$ & $>140$ & Ungu \\
Terjal & $35-55$ & $70-140$ & Merah \\
Curam & $16-35$ & $30-70$ & Merah muda \\
Agak Curam & $8-16$ & $15-30$ & Jingga \\
Landai & $4-8$ & $7-15$ & Kuning \\
Agak Landai & $2-4$ & $2-7$ & Hijau muda \\
Datar & $0-2$ & $0-2$ & Hijau \\
\hline
\end{tabular}

\subsubsection{Kerapatan Kelurusan}

Kerapatan kelurusan merupakan perhitungan panjang suatu kelurusan terhadap luas, dinyatakan dalam $\mathrm{km} / \mathrm{km} 2$. Kelurusan-kelurusan morfologi seperti kelurusan sungai, gawir, dan punggungan merupakan zona rekahan dan patahan yang umumnya terekspresikan di lapangan. Namun, kelurusan-kelurusan morfologi tersebut dapat diidentifikasi juga melalui foto udara atau citra satelit (Setiawan, 2016). Hasil kerapatan kelurusan ini dipakai untuk analisis pola dominan dan intensitas struktur geologi pada daerah penelitian berupa analisis densitas kelurusan. Perhitungan densitas kelurusan morfologi yang dilakukan berupa perhitungan lineament count density yang bertujuan untuk mengetahui konsentrasi dan pola penyebaran kelurusan-kelurusan morfologi (Setiawan, 2011). Tahapan dari perhitungan densitas kelurusan yaitu membagi daerah penelitian ke dalam beberapa grid dan menjumlahkan kelurusan yang berada pada sebuah luasan persegi empat atau kotak dengan panjang dan lebar tertentu.

\subsection{Hidrogeologi}

\subsubsection{Pengukuran Sifat Fisik Air Tanah dan Air Permukaan}

Pemetaan hidrogeologi dilakukan dengan cara pengamatan, pengukuran, pengujian dan pencatatan data di lapangan yang terkait dengan keadaan air tanah (Pratiknyo, 2016). 


\section{Jurnal Pendidikan Geografi:}

\section{Kajian, Teori, dan Praktik dalam Bidang Pendidikan dan Ilmu Geografi}

$$
\text { 27(2), 2022, 88-101 }
$$

Pengamatan meliputi pengukuran daya hantar listrik, zat padat terlarut, temperatur air, $\mathrm{pH}$ dan debit pada sejumlah mata air, sumur dan sungai yang diamati.

\subsubsection{Pengukuran Muka Air Tanah (MAT)}

Pengukuran nilai MAT dilakukan dengan menggunakan alat water level meter. Kedalaman muka air tanah diperoleh dengan cara melakukan pengukuran terhadap kedalaman sumur sampai menyentuh muka air tanah bebas (Sejati, 2020). Data MAT diolah menjadi data garis aliran (flownet) untuk mengetahui arah pergerakan air tanah (Prasetya et al., 2016). Pembuatan flownet menggunakan cara yang dikenal dengan Three Point Problem, yaitu menghubungkan beberapa tinggi muka air dengan suatu garis dari pengukuran kedalaman muka air tanah dengan cara interpolasi (Suprayogi et al., 2019).

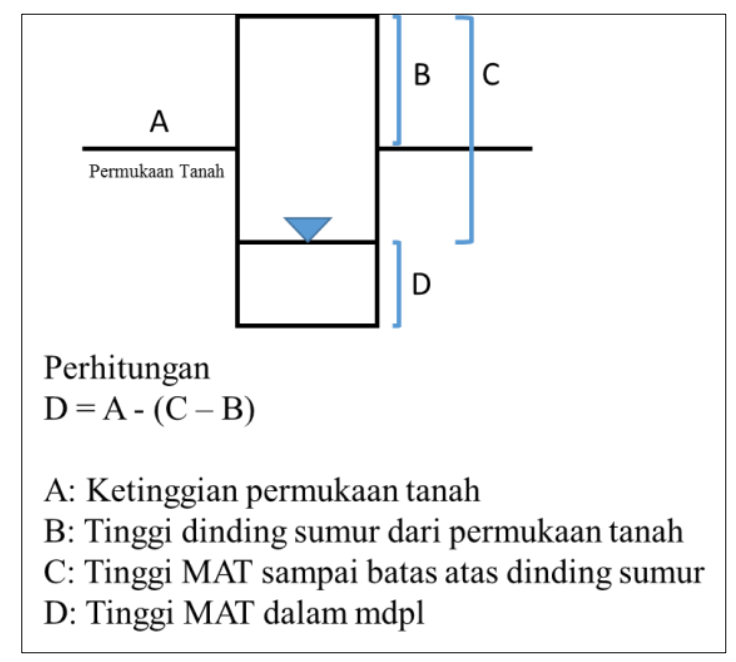

\section{Gambar 3. Ilustrasi Perhitungan Tinggi Muka Air pada Sumur}

\subsection{Analisis Overlay}

Dari hasil pembuatan peta geologi, peta kemiringan lereng, peta densitas kelurusan serta pengukuran sifat fisik air dan tinggi muka air tanah, kemudian dianalisis hubungan kondisi geologi terhadap karakteristik air tanah dan air permukaan di daerah penelitian dengan menghubungkan parameter-parameter terkait. Analisis hubungan menggunakan metode overlay yaitu suatu sistem informasi dalam bentuk grafis yang dibentuk dari penggabungan berbagai peta individu (memiliki informasi/database yang spesifik) (Rachmah, Rengkung, \& Lahamendu, 2018). Overlay dilakukan pada masing-masing peta yang di tumpang tindih dengan titik plot stasiun pengamatan. Hasil overlay tersebut menunjukkan keterkaitan antara peta-peta yang dibuat (parameter geologi) dengan titik plot stasiun pengamatan (parameter hidrologi) yang kemudian membentuk kelompok-kelompok air tanah-air permukaan serta faktor-faktor yang berkaitan. 


\section{Hasil dan Pembahasan}

\subsection{Geomorfologi dan Penginderaan Jauh}

Analisa geomorfologi dan penginderaan jauh dapat diterapkan untuk kegiatan pembelajaran dalam kerangka metode penelitian dengan menggunakan data sekunder. Hal ini memungkinkan proses dari suatu penelitian masih dapat dilakukan meskipun tidak memiliki data primer. Berikut ini secara berturut-turut dijelaskan tentang penggunaan pendekatan geomorfologi dan aplikasi penginderaan jauh untuk menganalisis karakter fisika air tanah dan air permukaan.

\subsubsection{Kemiringan Lereng}

Dari hasil analisa pada DAS di bagian selatan Gunung Manglayang, terdapat 5 kelompok kemiringan lereng, yaitu curam, agak curam, landai, agak landai dan datar. Klasifikasi kemiringan lereng datar didominasi di bagian selatan DAS. Klasifikasi kemiringan lereng agak landai relatif tersebar rata di bagian tengah daerah penelitian. Klasifikasi kemiringan lereng landai berada di sebagian utara dan tengah DAS. Klasifikasi kemiringan lereng agak curam didominasi di bagian sekitar puncak Gunung Manglayang dan Gunung Bukit Jarian. Keberadaan objek hidrogeologi di daerah penelitian umumnya berada pada klasifikasi datar sampai landai.

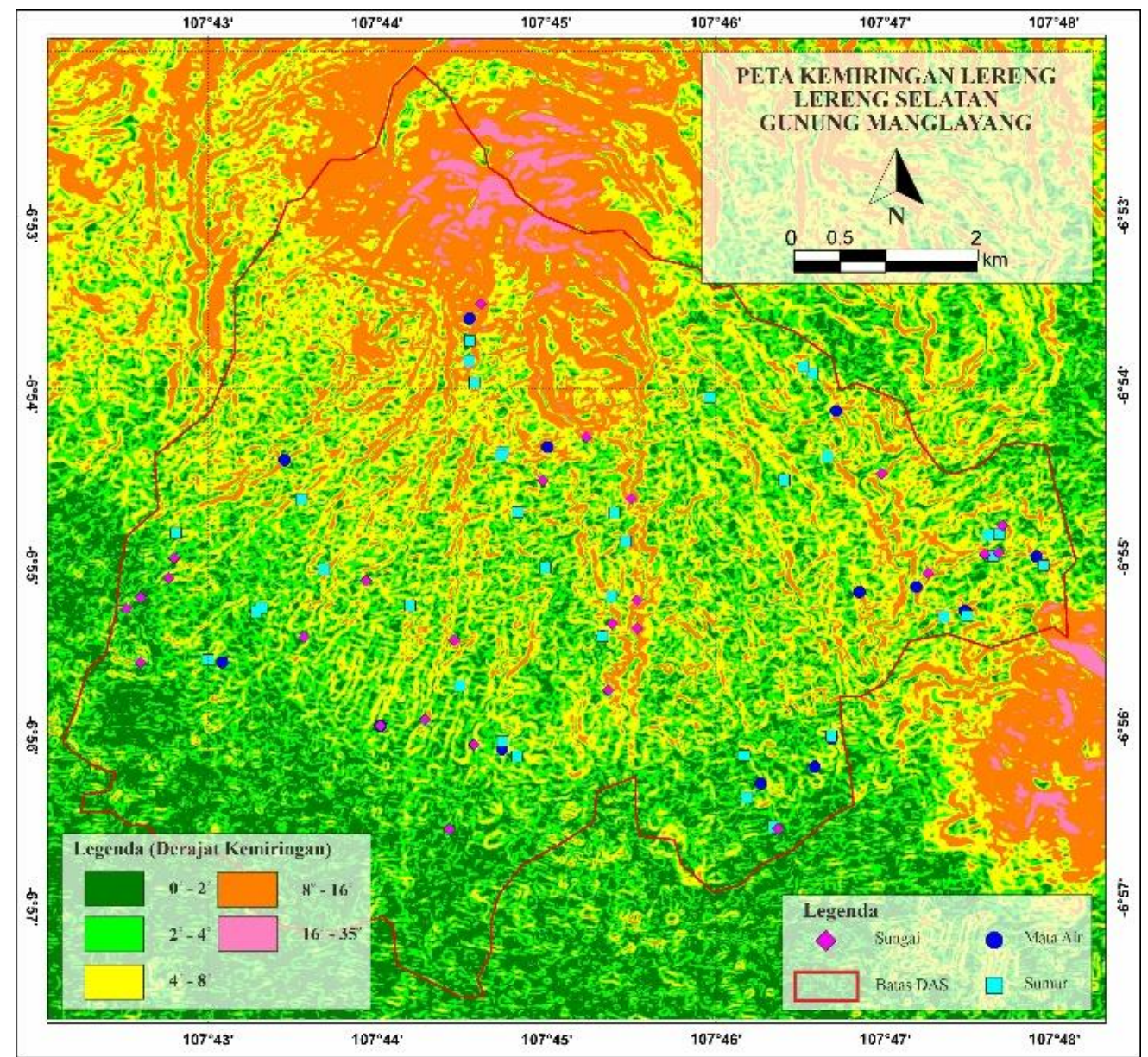

Gambar 4. Peta Kemiringan Lereng 
Jurnal Pendidikan Geografi:

Kajian, Teori, dan Praktik dalam Bidang Pendidikan dan Ilmu Geografi

27(2), 2022, 88-101

\subsubsection{Densitas Kelurusan}

Densitas kelurusan diinterpolasikan menggunakan metode kriging dan klasifikasi densitas dibagi berdasarkan pengaturan distribusi secara merata antara data minimum dan maksimum. Hasil analisis kelurusan menunjukkan variasi 5 tingkatan nilai dimulai dari densitas rendah sampai tinggi. Bagian selatan DAS didominasi densitas rendah. Bagian tengah DAS dan sekitar Gunung Bukit Jarian memiliki densitas agak rendah. Bagian tengah sampai utara daerah penelitian memiliki densitas sedang. Bagian tengah DAS (berupa titik sampel) dan bagian luar DAS sebelah utara memiliki densitas agak tinggi. Sedangkan di bagian utara batas luar daerah penelitian memiliki densitas tinggi.

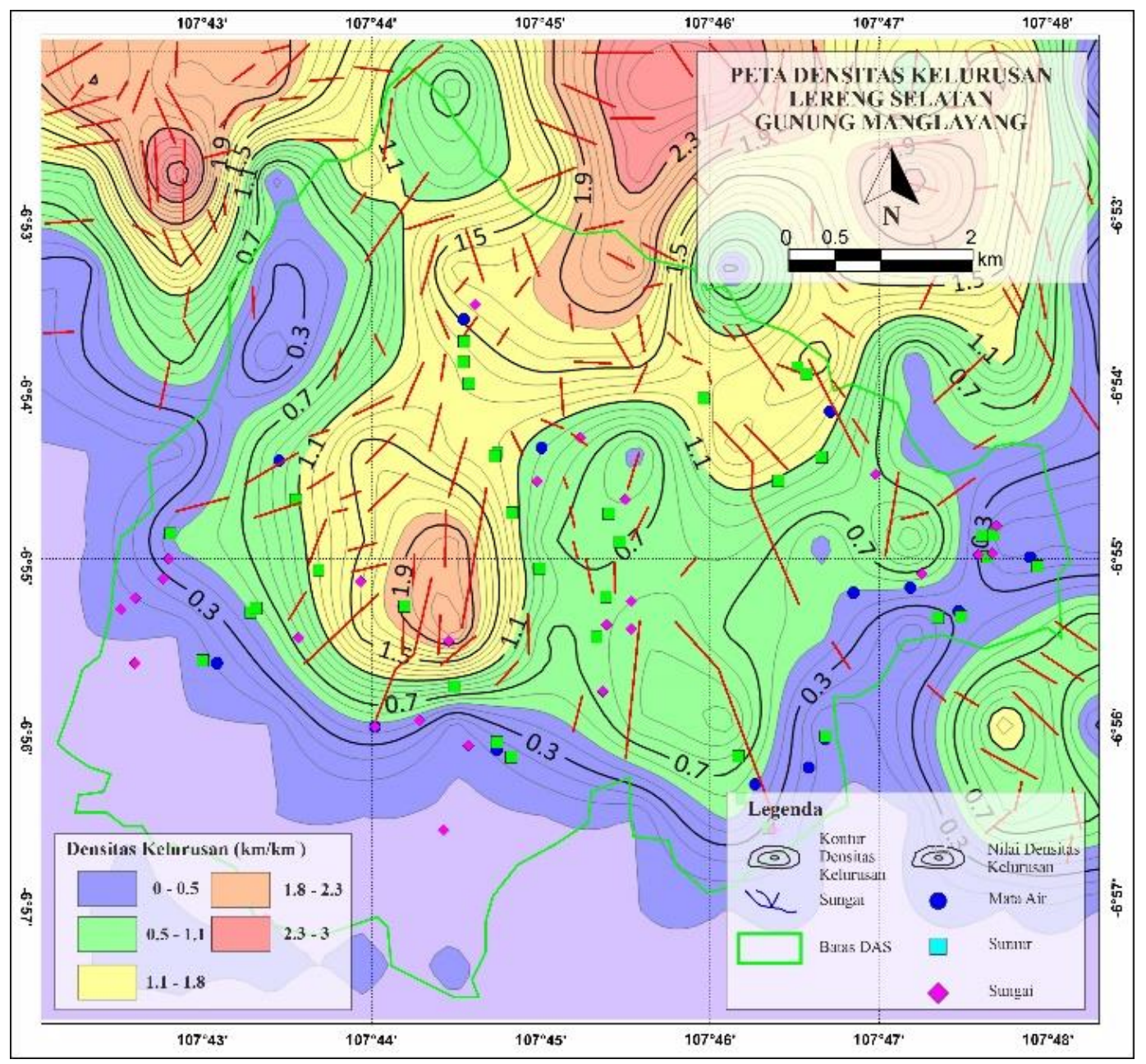

Gambar 5. Peta Densitas Kelurusan

\subsection{Analisa Hidrogeologi}

\subsubsection{Pola Aliran Air Tanah Dangkal}

Pola aliran air tanah dangkal di daerah penelitian ditentukan melalui beberapa objek pengamatan yaitu sumur-sumur warga dan mata air depresi. Pada daerah penelitian ditemukan sumur warga sebanyak 36 sumur dan lima mata air. Pada daerah penelitian, didapatkan kedalaman muka air tanah yang berkisar antara 1,3 m sampai 29,1 m. Data tersebut 


\section{Jurnal Pendidikan Geografi:}

\section{Kajian, Teori, dan Praktik dalam Bidang Pendidikan dan Ilmu Geografi}

$$
\text { 27(2), 2022, 88-101 }
$$

kemudian diolah menjadi peta atau gambar yang berisi kontur dan arah aliran air tanah yang dikenal sebagai flow nets (Todd \& Mays, 2004). Flow nets penelitian disajikan pada Gambar 6. Berdasarkan flow nets tersebut, dapat dilihat bahwa arah aliran air tanah permukaan di daerah penelitian umumnya dari utara ke selatan.

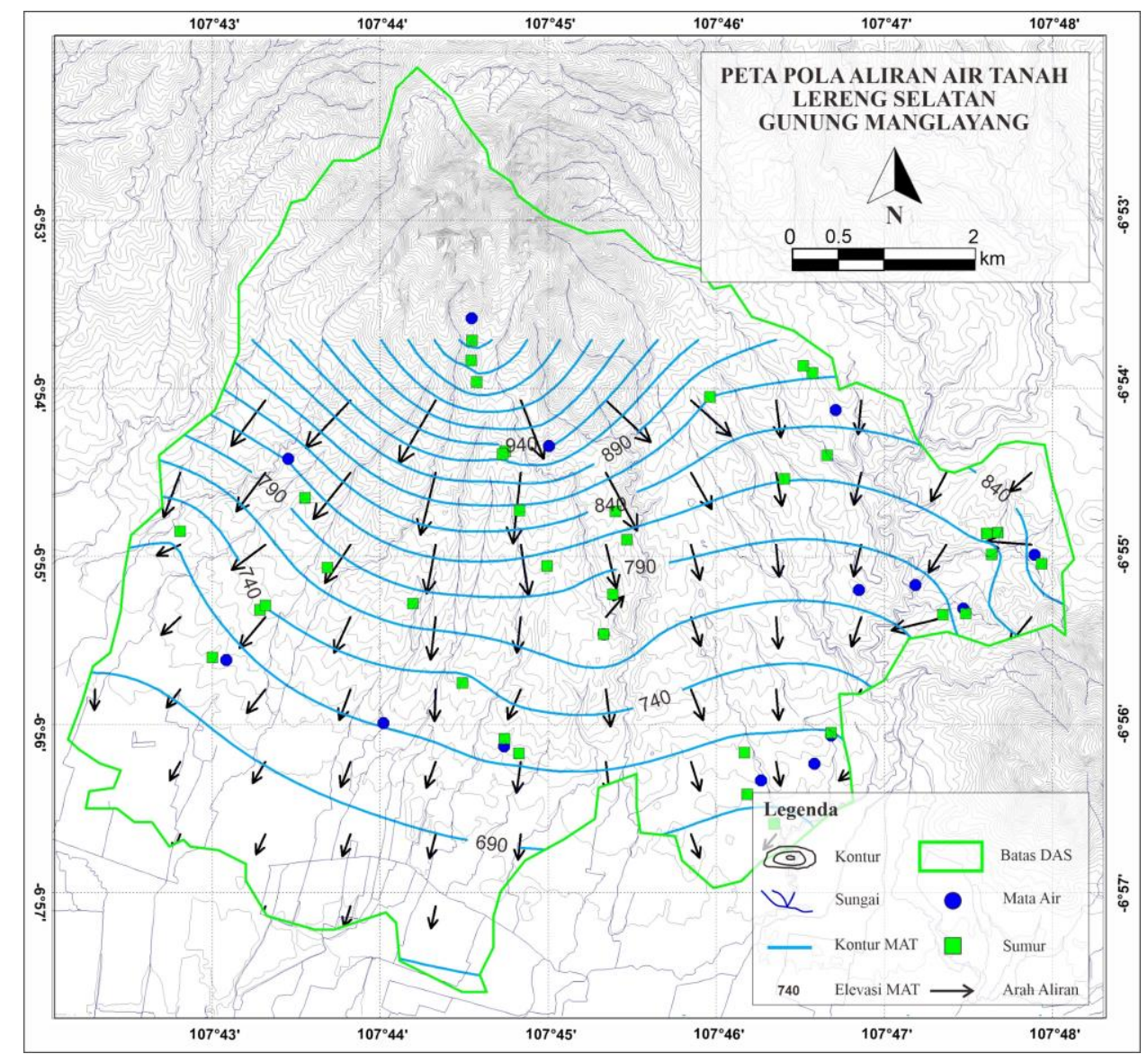

Gambar 6. Peta Pola Aliran Air Tanah

\subsubsection{Sifat Fisik Air}

Lokasi objek penelitian memiliki 26 sungai, 36 sumur, dan 15 mata air. Pengukuran dilakukan pada musim kemarau (Juni-Juli 2019), sehingga banyak sungai yang kering atau ada sedikit air yang mengalir di sungai. Hal yang sama juga terjadi pada lokasi di mata air dan sumur.

Ketiga jenis sub-DAS tersebut diukur sifat fisik airnya. Hasil pengukuran sifat fisik air sungai di lapangan mendapatkan hasil yaitu nilai TDS 63-490 mg/l, pH berkisar antara 6-7,7, dan EC berkisar antara 126-980 $\mu \mathrm{S} / \mathrm{cm}$. Secara umum nilai EC air sungai akan semakin tinggi apabila elevasinya semakin rendah. Hal ini dapat dilihat pada Gambar 7.

Hasil pengukuran sifat fisik air untuk air tanah pada objek sumur diperoleh nilai TDS 16$582 \mathrm{mg} / \mathrm{l}, \mathrm{pH}$ antara 5,3-7,6, dan EC berkisar antara 32-1.168 $\mu \mathrm{S} / \mathrm{cm}$. Nilai EC dari pengukuran ini dapat dilihat pada Gambar 8, yang menunjukkan bahwa Sub-DAS Cileles satu memiliki nilai EC rendah. Sub-DAS Cileles dua, sub-DAS Cikeruh satu, sub-DAS Cilameta satu, dan sub-DAS 
Jurnal Pendidikan Geografi:

Kajian, Teori, dan Praktik dalam Bidang Pendidikan dan Ilmu Geografi

$$
\text { 27(2), 2022, 88-101 }
$$

Cikeruh dua, memiliki EC yang sedang dan cenderung naik pada elevasi lebih rendah. Sub-DAS Cicaringin dan sub-DAS Cilameta dua cenderung memiliki nilai EC yang tinggi.

Sedangkan hasil pengukuran sifat fisik air untuk mata air diperoleh nilai EC berkisar antara 74-780 $\mathrm{SS} / \mathrm{cm}$, nilai TDS 39-390 mg/l, dan pH 5,8-7,4. Walaupun memiliki jumlah objek yang sedikit, terlihat pada Gambar 9, pola konsentrasi EC menunjukkan semakin rendah elevasi maka nilai EC menjadi meningkat. Sub-DAS Cileles dua memiliki nilai EC rendahsedang, sub-DAS Cicaringin, sub-DAS Cikeruh memiliki nilai EC tinggi, sub-DAS Cikeruh satu, dan sub-DAS Cilameta satu memiliki nilai EC rendah-tinggi.

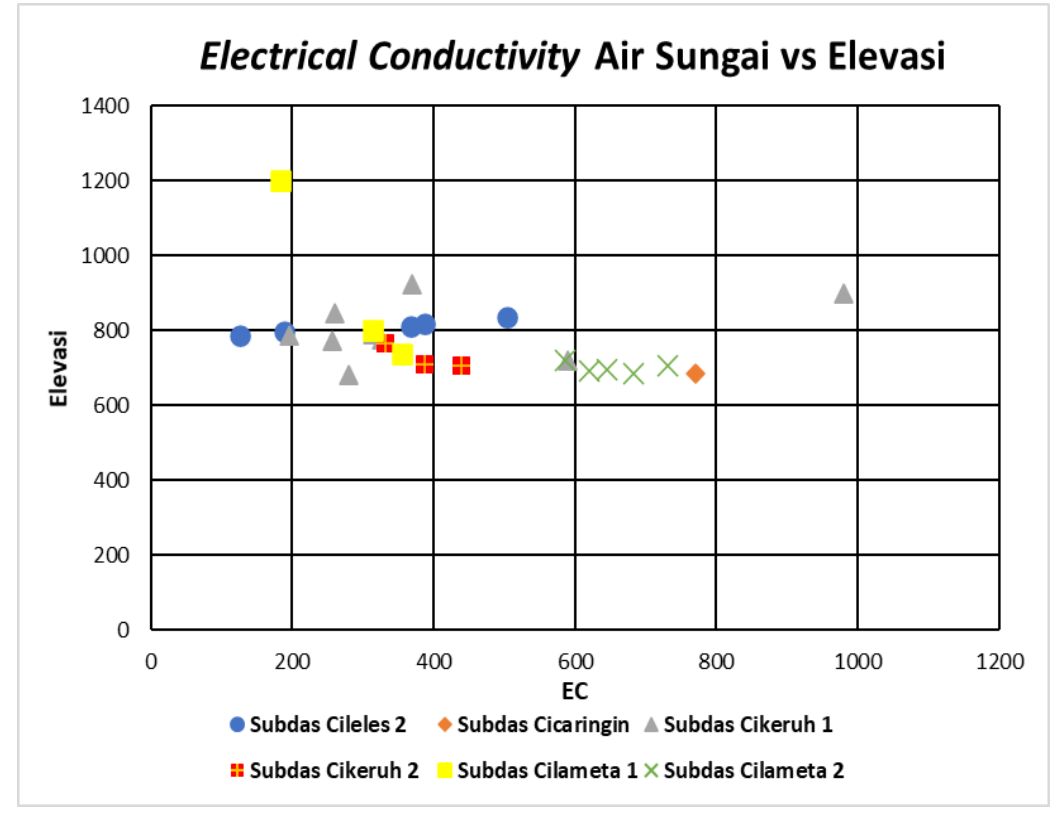

Gambar 7. Grafik EC Air Sungai Daerah Penelitian

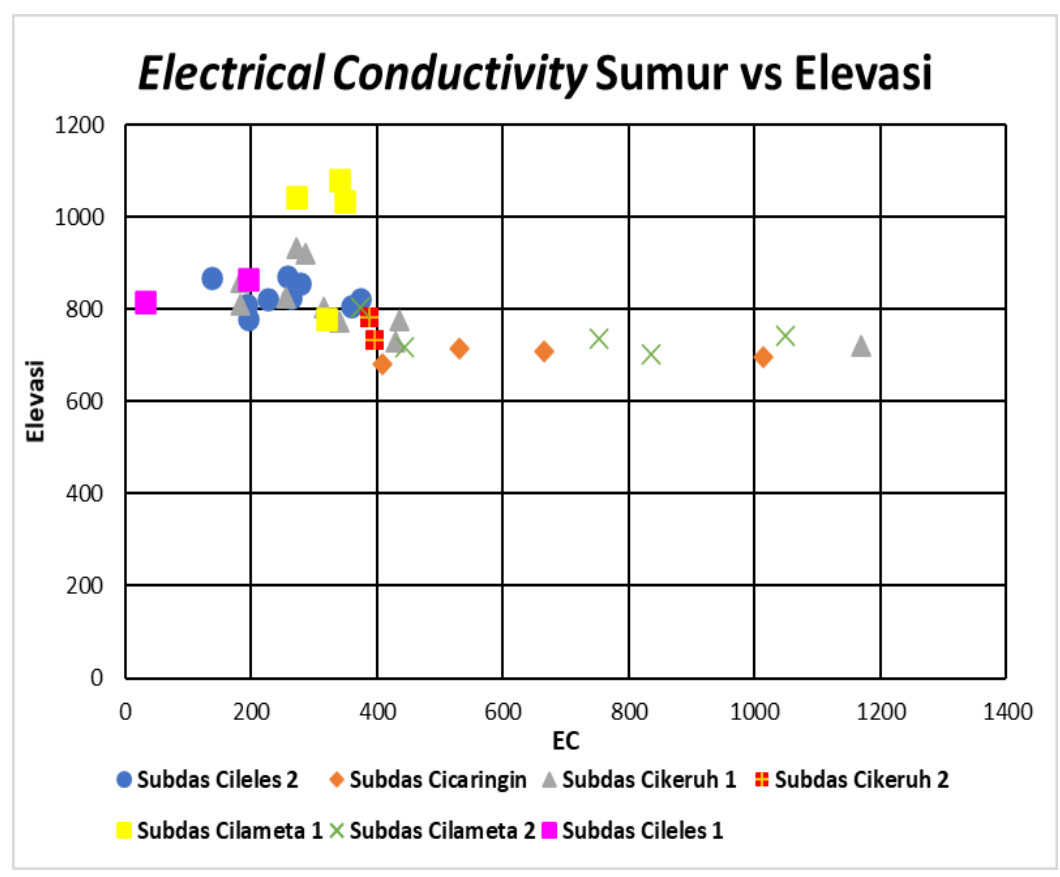

Gambar 8. Grafik EC Air Tanah (Sumur) di Daerah Penelitian 
Jurnal Pendidikan Geografi:

Kajian, Teori, dan Praktik dalam Bidang Pendidikan dan Ilmu Geografi

27(2), 2022, 88-101

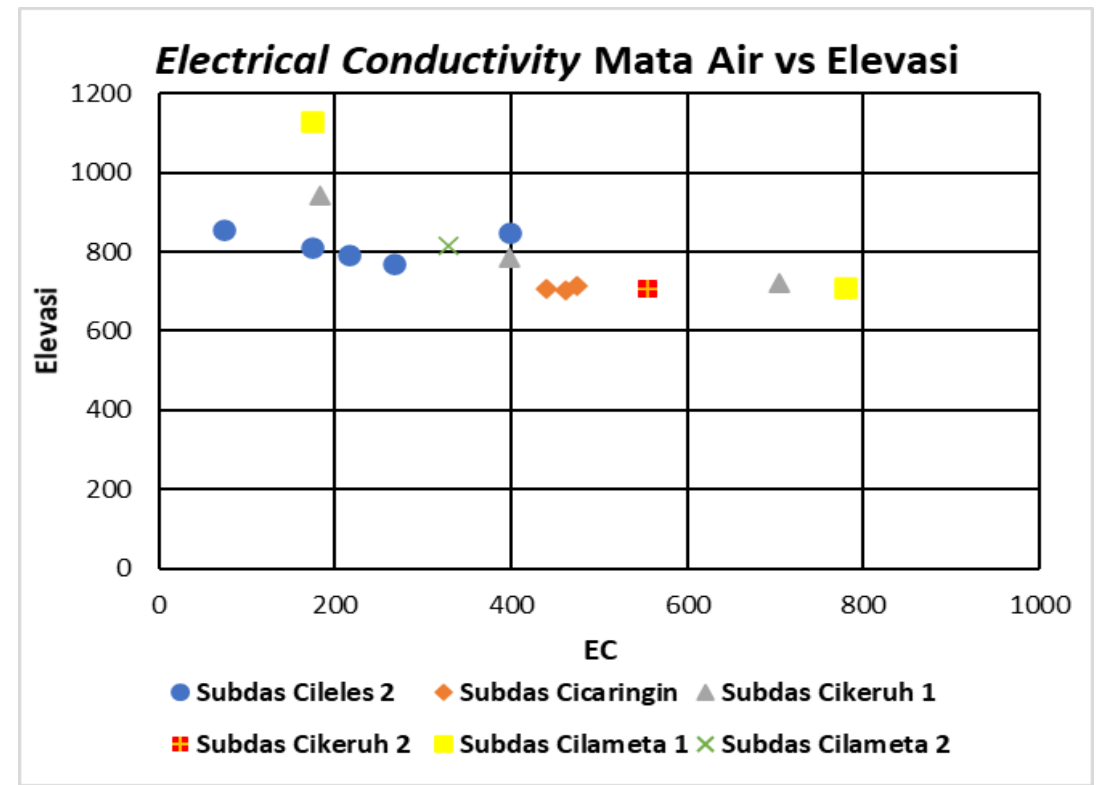

Gambar 9. Grafik EC Air Tanah (Mata Air) Daerah Penelitian

\subsection{Hubungan Karakteristik Air Tanah-Air Permukaan dengan Kondisi Geologi}

Hubungan karakteristik air tanah-air permukaan dengan kondisi geologi dapat dijelaskan sebagai berikut:

\subsubsection{Sub-DAS Cileles Satu dan Dua}

Pada sub-DAS Cileles satu dan dua, terdapat dua kelompok air tanah dan air permukaan. Kelompok satu merupakan aliran air yang berasal dari arah utara (Manglayang) sedangkan kelompok dua berasal dari arah timur daerah penelitian (Bukit Jarian). Kelompok satu memiliki sifat fisik air tanah dan air permukaan yang cenderung rendah-sedang $(<300 \mu \mathrm{S} / \mathrm{cm})$, dan pada kelompok dua cenderung tinggi $(>300 \mu \mathrm{S} / \mathrm{cm}$ ) (Gambar 9). Karakteristik air di subDAS ini dipengaruhi oleh faktor topografinya yaitu kemiringan yang agak landai sampai agak curam. Selain faktor topografi, kondisi geologi bagian utara sub-DAS ini tersusun oleh produk vulkanik muda dan bagian timur tersusun oleh produk vulkanik tua.

\subsubsection{Sub-DAS Cicaringin}

Karakteristik air tanah maupun air permukaan di sub-DAS Cicaringin memiliki sifat fisik air yang tinggi. Hal ini dipengaruhi oleh letak objek pengamatan yang berada pada elevasi rendah, kemiringan agak landai, dan ada pada bagian hilir. Selain itu, letak objek pengamatan tersebut membuat waktu perjalanan air tanah di dalam batuan cenderung lebih lama, dengan ditandai nilai EC yang cukup tinggi, yaitu sebesar 440-1.014 $\mu \mathrm{S} / \mathrm{cm}$. Kondisi hidrokimia ini merupakan cerminan panjang pendeknya waktu tinggal (residence time) dalam akuifer (Chebotarev, 1955). Selain itu, kondisi litologi pada sub-DAS ini tersusun oleh transisi dari breksi vulkanik dan endapan danau muda. 


\section{Jurnal Pendidikan Geografi:}

Kajian, Teori, dan Praktik dalam Bidang Pendidikan dan Ilmu Geografi

$$
\text { 27(2), 2022, 88-101 }
$$

\subsubsection{Sub-DAS Cikeruh Satu dan Dua}

Pada sub-DAS Cikeruh, kelompok air tanah dan air permukaan dibagi menjadi tiga. Kelompok satu berada di elevasi tinggi dengan kemiringan lereng agak curam, satuan batuan antara lava dan breksi vulkanik, densitas kelurusan sedang, dan EC air 182-370 $\mu \mathrm{S} / \mathrm{cm}$. Kelompok dua berada di bagian tengah sub-DAS dengan kemiringan landai-agak curam, breksi vulkanik, dan sifat fisik air dengan EC 200-400 $\mu \mathrm{S} / \mathrm{cm}$. Kelompok tiga berada di bagian hilir dengan kemiringan agak datar-agak landai, transisi dari breksi vulkanik, endapan danau muda, dan sifat fisik air yang tinggi $(\mathrm{EC}>500 \mu \mathrm{S} / \mathrm{cm})$.

\subsubsection{Sub-DAS Cilameta Satu}

Hasil analisis menunjukkan bahwa sub-DAS Cilameta satu terbagi menjadi tiga kelompok air. Kelompok satu mempunyai elevasi $>1000 \mathrm{mdpl}$ dengan kemiringan agak curam yang tersusun dari breksi vulkanik dominasi komponen dan lava andesit. Kondisi ini menjadikan sifat fisik air mempunyai EC rendah-sedang karena dekat daerah resapan air. Kelompok dua di sub-DAS ini mempunyai karakteristik air maupun geologi yang sama dengan sub-DAS Cikeruh kelompok dua. Kelompok tiga diwakili oleh objek mata air dengan nilai EC yang tinggi dan berada di bagian hilir daerah penelitian.

\subsubsection{Sub-DAS Cilameta Dua}

Terdapat dua kelompok air tanah-air permukaan pada sub-DAS Cilameta dua. Kelompok satu berada di elevasi $>800$ mdpl dengan kemiringan lereng agak curam, breksi vulkanik, dan nilai sifat fisik air tanah sedang $(\mathrm{EC}<400 \mu \mathrm{S} / \mathrm{cm}$ ). Sementara itu kelompok dua memiliki elevasi $<750$ mdpl dengan kemiringan datar-agak landai, kondisi batuan merupakan transisi dari endapan vulkanik ke endapan danau, dan nilai sifat fisik air tinggi (EC>400 $\mu \mathrm{S} / \mathrm{cm})$.

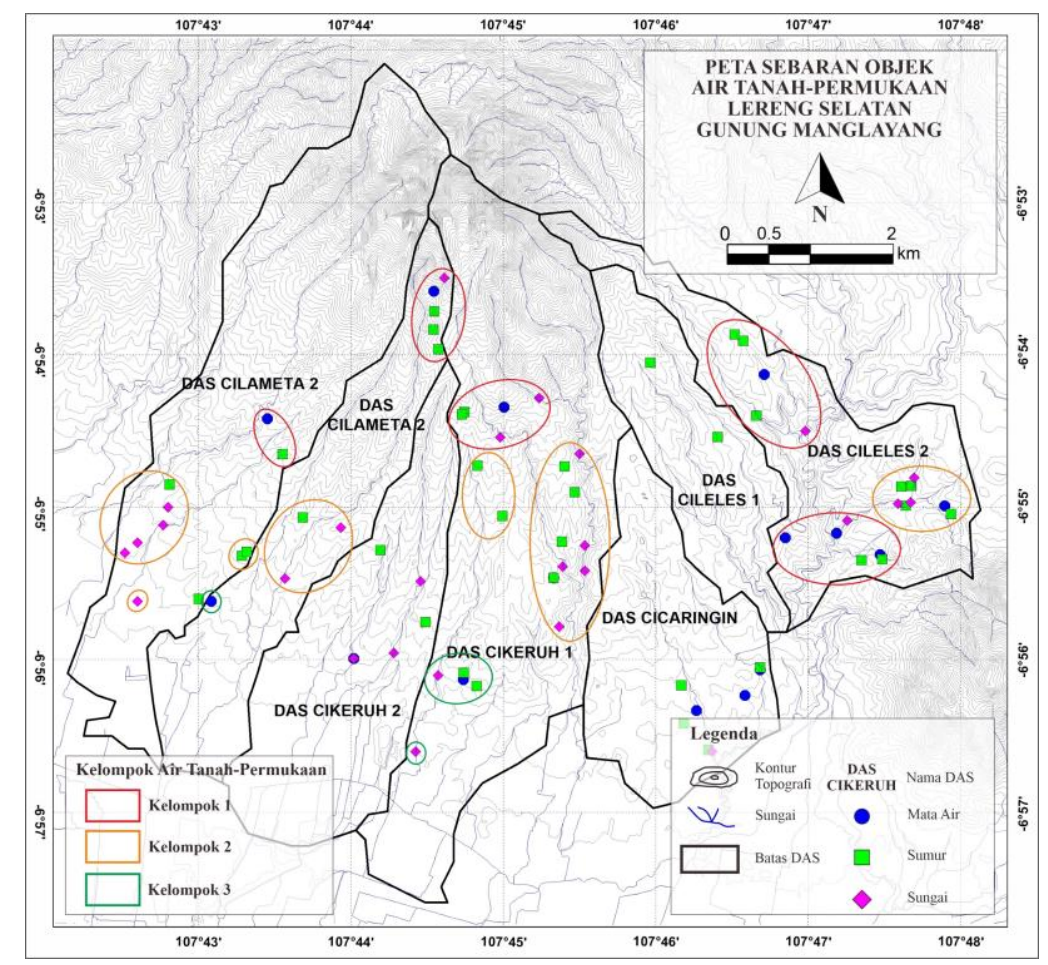

Gambar 10. Peta Sebaran Objek Air Tanah-Air Permukaan 


\section{Simpulan}

Hasil analisis overlay data menunjukkan adanya hubungan yang erat antara kondisi geologi dan air tanah-air permukaan khususnya faktor morfologi dan faktor litologi. Kemiringan lereng datar-landai yang berada di hilir mempunyai sifat fisik air yang lebih tinggi dari pada kemiringan lereng agak curam yang berada di hulu. Berdasarkan kondisi batuan, transisi satuan endapan vulkanik dengan endapan danau sedimen terlihat mempunyai nilai sifat fisik air tanah yang lebih tinggi dibandingkan dengan endapan vulkanik di bagian hulu daerah penelitian. Hasil penelitian juga menunjukkan bahwa kelompok air tanah-air permukaan terbagi menjadi tiga, yaitu kelompok satu umumnya berada di hulu DAS, kelompok dua umumnya berada di tengah DAS, dan kelompok tiga berada di hilir DAS. Nilai sifat fisik air pada kelompok tiga yang cenderung tinggi dan berada pada lahan pemukiman perlu dikelola dengan baik pemanfaatan airnya sehingga kualitas dan kuantitas air dapat terjaga. Penelitian ini bermanfaat mengembangkan khasanah pengetahuan dan aplikasi dalam mata kuliah hidrologi, geohidrologi, pengelolaan DAS, dan kualitas air. Praktik yang dilakukan dapat diterapkan dalam perkuliahan sehingga mampu menjembatani kebutuhan teoritis dan praktis.

\section{Daftar Rujukan}

Badan Informasi Geospasial. (2018). DEMNAS seamless Digital Elevation Model (DEM) dan Batimetri Nasional. Badan Informasi Geospasial. http://tides.big.go.id/DEMNAS/Jawa.php

Badan Pusat Statistik Kabupaten Sumedang. (2019). Kecamatan Jatinangor dalam angka 2019. Bandung.

Chebotarev, I. I. (1955). Metamorphism of natural waters in the crust of weathering-1. Geochimica et Cosmochimica Acta, 8(1-2), 22-48.

Hadian, M. S. D., Barkah, M. N., Sistanto, B. A., \& Helmi, F. (2017). Zonasi daerah rawan dan kritis kontaminasi air tanah dangkal di daerah Jatinangor dan sekitarnya. Seminar Nasional Fakultas Teknik Geologi Ke-3 Universitas Padjadjaran "Peran Geologi dalam Pengembangan Pengelolaan Sumber Daya Alam dan Kebencanaan", 24-25. Universitas Padjadjaran.

Ismawan, T. (2013). Peran sesar terhadap karakter dan arah aliran air tanah pada endapan vulkanik di lereng tenggara G. Gede, Kabupaten Cianjur, Jawa Barat. Bulletin of Scientific Contribution: Geology, 11(1).

Jumhari, J., Hadian, M. S. D., Zakaria, Z., \& Hendarmawan, H. (2019). Kontrol geologi terhadap perubahan kimia air tanah pada sistem akuifer vulkanik di lereng timur Gunung Ciremai Jawa Barat. Dinamika Rekayasa, 15(2), 117. https://doi.org/10.20884/1.dr.2019.15.2.267

Muslim, D., \& Endyana, C. (2015). Pentingnya identifikasi patahan aktif dalam upaya mitigasi bencana di kawasan pendidikan Jatinangor, Jawa Barat. Bulletin of Scientific Contribution: Geology, 13(2).

Oki, T., \& Kanae, S. (2006). Global hydrological cycles and world water resources. Science, 313(5790), 10681072. https://doi.org/10.1126/science.1128845

Prasetya, D. A., Waspodo, R. S. B., \& Saptomo, S. K. (2016). Prediksi cadangan air tanah di Daerah Aliran Sungai (DAS) Cisadane. Jurnal Teknik Sipil dan Lingkungan, 1(2), 59-68.

Pratiknyo, P. (2016). Teknologi mineral. Jurnal Ilmu Kebumian Teknologi Mineral, 28(1), 27-39.

Rachmah, Z., Rengkung, M. M., \& Lahamendu, V. (2018). Kesesuaian lahan permukiman di kawasan kaki Gunung Dua Sudara. Spasial, 5(1), 118-129.

Rahman, M. B. (2016). Income pattern characteristics of goods and services providers. Tata Loka, 18(1), 1-10.

Sejati, S. P. (2020). Potensi pencemaran air tanah bebas pada sebagian kawasan resapan air di lereng selatan Gunungapi Merapi. Jurnal Pendidikan Geografi: Kajian, Teori, dan Praktik dalam Bidang Pendidikan dan Ilmu Geografi, 25(1), 25-38. https://doi.org/10.17977/um017v25i12020p025

Setiawan, T. (2011). Deliniasi kelurusan morfologi sebagai dasar untuk menentukan zona potensi resapan mata air kars di daerah Luwuk, Sulawesi Tengah. Buletin Geologi Tata Lingkungan, Vol. 21, pp. 105116.

Setiawan, T. (2016). Sistem akuifer kars Waekabubak, Sumba Barat, berdasarkan analisis densitas kelurusan morfologi dan variasi spasial hidrogeokimia. Jurnal Lingkungan dan Bencana Geologi, 7(2), 89-102. 
Jurnal Pendidikan Geografi:

\section{Kajian, Teori, dan Praktik dalam Bidang Pendidikan dan Ilmu Geografi}

$27(2), 2022,88-101$

Soetrisno, S. (1983). Peta hidrogeologi Indonesia lembar V Bandung skala 1:250.000. Bandung: Direktorat Geologi Tata Lingkungan.

Sugianti, K., Mulyadi, D., \& Maria, R. (2016). Analisis kerentanan pencemaran air tanah dengan pendekatan metode DRASTIC di Bandung Selatan. Jurnal Lingkungan dan Bencana Geologi, 7(1), 19-33.

Suprayogi, S., Fatchurohman, H., \& Widyastuti, M. (2019). Analisis kondisi hidrologi terhadap perkembangan wilayah perkotaan studi kasus DAS Kali Belik Yogyakarta. Jurnal Geografi: Media Informasi Pengembangan dan Profesi Kegeografian, 16(2), 153-161. https://doi.org/10.15294/jg.v16i2.22364

Taryana, D. (2015). Pengaruh formasi geologi terhadap potensi mata air di Kota Batu. Jurnal Pendidikan Geografi: Kajian, Teori, dan Praktik dalam Bidang Pendidikan dan Ilmu Geografi, 20(2), 9-19. https://doi.org/10.17977/um017v20i22015p009

Todd, D. K., \& Mays, L. W. (2004). Groundwater hydrology. John Wiley \& Sons.

Wahyudi, W., Suganda, B. R., Sendjaja, Y. A., Hadian, M. S. D., \& Irawan, B. (2019). Karakteristik kimia organik pada akifer bebas di beberapa lokasi pemanfaatan lahan daerah Jatinangor dan sekitarnya. Bulletin of Scientific Contribution: Geology, 17(3), 205-212.

Zuidam, R. A. van. (1986). Aerial photo-interpretation in terrain analysis and geomorphologic mapping. Smits Publishers. 